\title{
Fatma Ayhan
}

Ankara Hacı Bayram Veli University, fatma.ayhan@hbv.edu.tr, Ankara-Turkey

\begin{tabular}{l|l|l}
\hline \hline DOI & http: //dx.doi.org/10.12739/NWSA.2021.16.1.4C0241 \\
\hline ORCID ID & $0000-0002-1777-8068$ \\
\hline CORRESPONDING AUTHOR & Fatma Ayhan \\
\hline \hline
\end{tabular}

\section{BUGÜN GIYIILEN MODERN GIYSİNIN OLUŞUMUNDA TÜRKLERINN ETKİSİ}

\section{Öz}

Bu çalışmada bugün giyilen modern giysinin oluşumunda Türklerin etkisi incelenmiştir. Giyim insanlıkla birlikte olan, ilkel toplumdan çağdaş topluma geçerken önemini daha fazla arttıran bir olgudur. Giyim maddi kültürün bir ögesidir, fakat aynı zamanda toplumsal bir içeriğe sahiptir. Kültür olgusunun beslendiği örf, adet, gelenek ve görenek kavramları giyim tarzları, üzerinde farklılıklar oluşturur. Giyim, elbise, çamaşır, saç şekilleri, makyaj, aksesuar başa ve ayağa giyilenlerin tümü demektir. Bu çalışmada bugünkü modern giyimin kökeninin Orta Asya Türklüğünden geldiğini, bu giysilerin bozkır tarzı giyimin, Çin'de M.Ö. 4. yüzyılda, Avrupa'da M.S. 5. yüzyılda Bizans'ta, 6. yüzyıldan itibaren Türk geleneksel giysi şekline göre yapılan askeri ıslahat sonucunda dünyaya yayıldığı anlatılmaya çalışılacaktır.

Anahtar Kelimeler: Giyim, Moda, Orta Asya, Avrupa, Türk

\section{THE EFFECTS OF TURKLER IN THE FORMATION OF THE MODERN GIBS TODAY}

\section{ABSTRACT}

In this study, the effect of the Turks on the formation of modern clothing worn today was investigated. Clothing is a phenomenon that is together with humanity and increases its importance more when moving from primitive to contemporary society. Clothing is an element of material culture, but it also has social content. The concepts of tradition, in which the cultural phenomenon is fed, create differences in the styles of clothing. Clothing means clothes, laundry, hairstyles, make-up, accessories are all that is worn on the head to the feet. In this study, the origins of today's modern clothing originate from Central Asian Turkishness and the steppe style clothing of these clothes in $\mathrm{BC}$ in China. In the 4 th century $\mathrm{AD}$ in Europe. It will be tried to be explained that it spread to the world in the 5 th century Byzantine as a result of the military reform made according to the Turkish traditional dress style from the 6th century.

Keywords: Clothing, Fashion, Central Asia, Europe, Turkish 


\section{GİRIŞ (INTRODUCTION)}

Türkler çok köklü bir ulustur. Türklerin kültür varlıklarından birisi de giyim kuşamdır. Türk giyim kuşam kültürü dünyada yerini aldığından bu yana geçen süre içinde özellikle günümüzde dünya modern giyim kuşamına önemli etkilerde ve katkılarda bulunmuştur. Bu katkılar ilk, orta, yeni ve yakın çağlarda sanatsal, bilimsel, teknik, felsefi ve eğitimsel boyutlarda giyim kültüründe birbirinden farklı özellikler taşımaktadır. Bu nedenle bu çağlarda Türk giyim kültürü kendine özgü evrilirken süreç içinde önce Asya'da sonra Avrupa ve tüm dünyada olmak üzere çeşitli ulusların giyim kültürleri ile etkileşim içine girmiştir. Giyim kültürümüz son 2500 yıllık döneminin yaklaşık yarısını en az üç kez büyük ölçekli imparatorluk giyim kültürü olarak geçirmiştir. Öncelikle Hun imparatorluğu ile Avrupa'ya taşınmış, üç kıtada farklı giyim kuşam kültürleriyle iç içe yaşamış, etkileşim içine girmiştir. Bu yaşayış ve etkileşimlerin kalıcı izleri zamanla belirli dünya giyim kültürlerinin anlamll birer ögesini oluşturmuşlardır. Türklerin giyim kültürlerinin Orta Asya'da geçirdiği ilk oluşum-gelişim evresinden sonra Asya' da çevre kültürlerle etkileri ve katkıları gerçekleştirdikleri büyük göçlerle başladı. Sonra ilk anlamlı etki ve katkıları M.Ö. 2. yüzyılda kültürlere olan etkiler ve katkılar izledi. Giysi tasarımında çok çeşitli etkilenme kaynakları olmakla birlikte, bunların en önemlilerinden bir tanesi kültürel etkilenmelerdir. Özellikle de ürün çıkışlı tasarımlarda tarihsel ve geleneksel giysilerden çıkışlı yeni giysi tasarımları büyük önem taşımaktadır [17]. Bu bağlamda kültürler arası alışverişin en belirgin şekilde gözlendiği alanlardan birisinin de giyim modası olduğu söylenebilir. Günümüz giyim modasının, farklı kültürlerarası etkilenmelere sahne olsa da hem kişiye özel yorumları hem de etkilendiği kültürel değerleri yansıtacak tarzda tüm insanların birlikte katkıda bulunduğu ortak bir ifade şeklinde dönüştüğü de göz ardı edilmemelidir. Uluslararası kostüm tarihçileri, Türk giyim kültürünün, dünya giyim tarihinde önemli olduğunu vurgulamaktadırlar. Ancak bugüne kadar Batı modasının Türk giyim tarzının Batıya etkileri üzerine aynı şeyi söylemek pek mümkün değildir [14 ve 17].

\section{2. ÇALIŞMANIN ÖNEMI (RESEARCH SIGNIFICANCE)}

$\mathrm{Bu}$ çalışmada öncelikle Avrupa ve Türk giyim kültürlerinin temel form ve karakteristik tasarım detayları incelenerek günümüz giyim modasına farklı yansımaları hazır giyim tasarımc markalarının koleksiyonları incelenerek saptanmaya çalışılmıştır. Farklı sitelerin yanı sıra Asya, Avrupa kütüphane ve müze araştırmaları ile moda okulları alanlarında uzman kaynak kişilerden yararlanılmıştır. Ayrıca çalışmada, Türk giyim kültürü ele alınmış, yapısal tasarım özellikleri üzerinde durulmuştur. Türk giyim kültürünün Batı ve günümüz global giyim modasını ne şekilde etkilediğini sağlıklı bir şekilde yorumlayabilmek için her şeyden önce her iki temel kültürün giyim karakteristiklerini ve estetik değerlerini iyi yorumlamak gerekir [16].

\section{AVRUPA VE TÜRK GIYİM KÜLTÜRLERININN TEMEL FORMLARI (BASIC FORMS OF EUROPE AND TURKISH CLOTHING CULTURES)}

Avrupa giyim kültürünün en temel karakteristik özelliğinin, Doğunun tersine, bu giysilerin vücudu sarması ve vücut hatlarını ortaya koyması olduğunu ifade eder. Örneğin; Ortaçağın başlarında erkek ve kadın giysilerinin üst kısımları üst bedene sıkıca bağlanarak oturulurken, alt bedende kadınlar da bileğe kadar uzanan uzun, erkekler de ise dizleri ortaya çıkaracak şekilde kısa etekler giyilmekteydi. Bu dönemde erkekler, eteğin altına her bir bacağı tek tek sıkıca saran ya da bacağa bağlanarak sarılan hortum şeklinde dizlikler kullanılmaktaydı. Pelerin, kolsuz manto gibi üst giysiler 
giyilmesine rağmen, Doğunun tersine, Batıda haçlı seferlerinden önce pantolona benzer her iki bacağı ayrı ayrı içine alan paçalı alt beden giysi formlarının giyilmediği bilinmektedir. Doğuda olduğu gibi kol kesimli, önden açık giysiler de Batıda bu dönemde kullanılmaktaydı. Benzer şekilde Doğu giyiminde hem fonksiyonel hem de estetik bir anlayış olarak benimsenmiş olan üst üste, katlı giyim tarzları da bu dönemde pek bilinmiyordu. Batı giyim kültüründe, giysinin vücuda oturmasını sağlayacak kesimler, yan dikiş eksenleri, pensler gibi ustalık isteyen giysi formlarının ve dikiş özelliklerinin 14. yy. Avrupa'sında ilk olarak kullanılmaya başlandığı bilinmektedir. Diğer taraftan Batı toplumunda kadınlar 19. Yy'ın ortalarında ancak uzun eteklerin dışında pantolon giymeye başlamışlardır [13]. Tarihsel gelişim sürecinde batılı giyim tarzının en karakteristik özelliklerini şu şekilde özetleyebiliriz. Vücut konturlarını ortaya çıkaracak tarzda, vücudu saran formlar, özellikle de üst bedeni sıkıca saran, vücuda oturan formlar ve ustalıklı dikim teknikleri görülmektedir. Alt bedende, kadınlar da bileğe kadar uzun, erkekler de kısa etek formları Pantolon yerine, erkeler de her bir bacağı tek tek sıkıca saran ya da bacağa bağlanarak sarılan hortum şeklinde dizlikler Batılı giyim kültüründe cinsiyet ayrımı çok daha belirgin; erkekler de önceleri dizlik, daha sonralarl pantolon formlarl, kadınlar da uzun etekler. Önü kapalı, baştan giyilip çıkarılabilen tunik şeklinde üstlükler. Giysi formları, süslemeleri, konstrüksiyonları hızlı bir değişime uğramış ve gelişmiştir. Giysilerde kopça kullanılmıştır. Türkler tarih boyunca başta Avrupalılar olmak üzere birçok ulusu ve Batı dünyasını etkilemişlerdir. Kaşgarlı Mahmut tarafından 11. yy 'da yazılan Divan-ü Lügat-it Türk adlı eser 8. yüzyıldan kalma Göktürk yazıtları, eski Uygur duvar resimleri ve Lazslo Rasonyi'nin "Tarihte Türklük" adlı eseri pantolon, çizme, cepken, etek, kemer, üç etek, ceket ve gömlek gibi giyim eşyalarının ilk kez Türk'ler tarafından giyildiğini ve orta Asya'dan dünyaya yayıldığını göstermektedir [12]. Orta Asya göçebe step ulusu olarak Türklerin ataları olan Hunların, Batı dünyasına taşıyıp benimsedikleri ve sonradan pantolona dönüşen şalvar altlıklar yalnız, Türkler açısından değil giyim tarihi açısından da olağanüstü öneme sahiptir [8].

Diğer taraftan, Türk giyim kuşam kültürünün en karakteristik özellikleri şunlardır:

- Giyside cinsiyet ayrımı pek belirgin değil. Hem erkekler hem de kadinlar benzer giysileri kullanmakta [28].

- Hem erkek hem de kadın için, hareket serbestisi sağlayan, bol kesimli rahat formlar [28].

- Kol kesimli, önden açık üstlükler; kaftanlar, entariler, cepkenler, yelekler [3].

- Şalvar şeklinde bol kesimli pantolon formları ve fuzo çeşitleri [4].

- Çok katlı, üst üste giyim tarzları (Şekil 1) [4]. Şalvar üstüne uzun üstlük, entari, kaftan vb. giyimi (Şekil 1) [4].

- Arma kullanımı Göktürk süvarilerinde başlıyor (Şekil 1) [4].

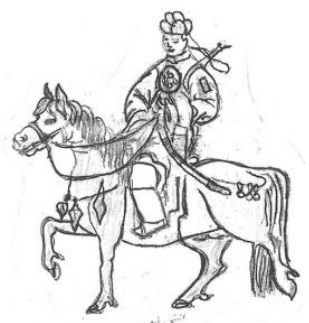

Şekil 1. Armalı süvari

(Image 1. Coat of arms) 
- Önü açık üstlükleri kapatmak ve aynı zamanda silah, çeşitli kişisel eşyaları taşıyabilmek için çeşitli kuşak kullanımı ve bağlamaları (Şekil 2) [4].

- Sarkıntılı kemer kullanılır, bu kemere çatal, kaşık, bıçak ve çeşitli aparatlar tutturulur (Şekil 2) [4].

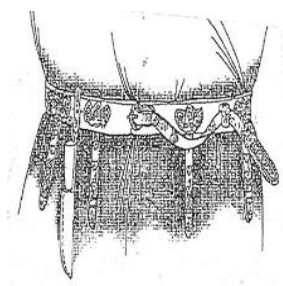

Şekil 2. Sarkancalı kemer (Image 2. Dangle belt)

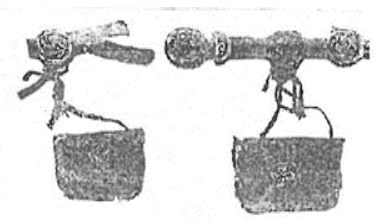

Şekil 3. Kemerde kullanılan çanta (Image 3. Bag used on the belt)

- Cinsiyet, zenginlik ya da statüler arası fark genellikle aksesuarlarla ve özellikle de başlıklar ile belirleniyordu (Şekil 4) [4].

- Başlıklar, türbanlar ve gösterişli süslemeler ile bezenir (Şekil 4) [3].
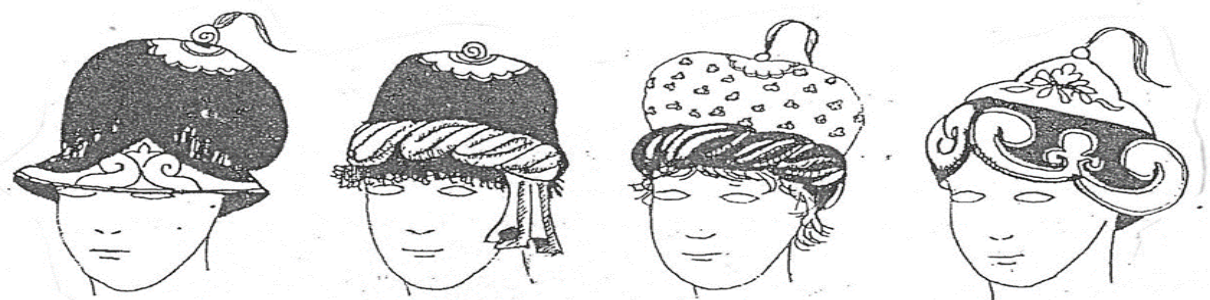

Şekil 4. Anadolu'ya gelmeden önce Türklerin giydiği değişik başlıklardan örnekler

(Image 4. Examples of different headgear worn by Turks before coming to Anatolia)

- Sarkan kol ağzı formları [3] .

- Kapaniçe denilen kürkle astarlanmış kaftanlar, kışlık giysiler kürkle kaplanır [3].

- Temel giysi formları uzun süre pek değişmemiş, daha ziyade materyal ve desen özellikleri değişmiştir [3].

- Kürklü pantolonlar [3].

- Giysilerde ilik düğme kullanılmıştır [4].

- Türk yakası, yaka kapama giysi özelliklerindendir (Şekil 5 ve 6; Fotoğraf 1 ve 2) [3].

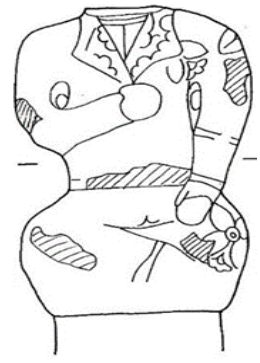

Şekil 5. Türk yakası (Orhun Anıtları) (Image 5. Turkish side)

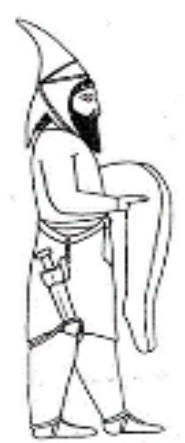

Şekil 6. Pazırık

(Image 6. Pazırık) 


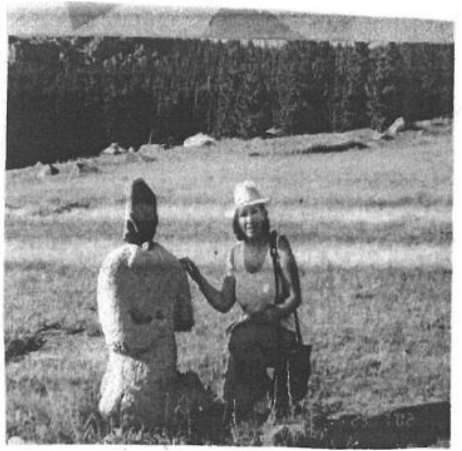

Fotoğraf 1. Türk yakası (Kağan Yaka) (Fatma Ayhan Arşivi)

(Photograph 1. Turkish side)

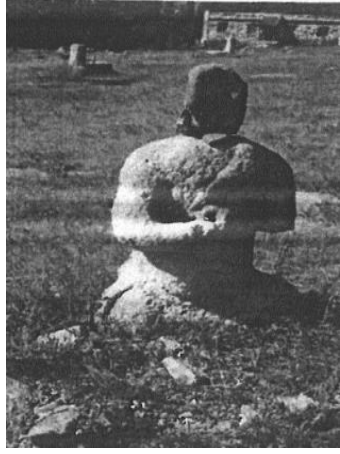

Fotoğraf 2. Yaka kapama

(Fatma Ayhan Arşivi)

(Photograph 2. Collar closure)

- Şal yaka (Bilge Kağan) (Fotoğraf 3; Şekil 7) .

- Soldan sağa kapama vardır (Şekil 7) [3].

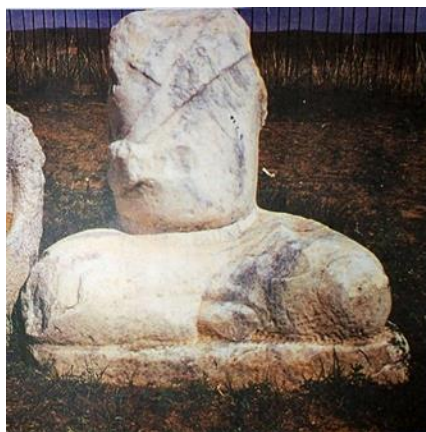

Fotoğraf 3. Bilge Kağan (Yakası soldan sağa doğru kapanıyor) (Fatma Ayhan Arşiv)

(Photograph 3. Bilge Kağan (The collar is closing from left to right))

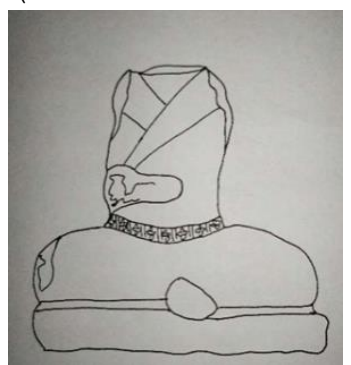

Şekil 7. Erkek giyiminde sol yaka üstte kalıyor

(Image 7. Left collar stays above men's clothing)

- Giysilerde aksesuar ve farklı objelerde Türk damga motifleri kullanılır [3].

- Erkeklerde uzun saç ve bıyık kullanılır [6].

- Erkeklerde tek ve çift küpe kullanılır. Kırgızistan şaman mezarlıklarındaki balballarda uzun saçlı, bıyıklı, tek ve çift küpeli erkek mezar taşlarında bu özellikler görülmektedir [6] .

- Elbiselerde yan, kol vb. yerlerde yırtmaç kullanılır [3].

- Giysilerde ütü kullanılır [3].

- Üst giysi palto (paltu) Turan kavmi olan Sümerlerle başlamıştır [3].

- Ayakkabıların numaralama sistemi çift motifle sağlanmıştır [3].

- Askerlerde uzun dizlikli çizme kullanılmıştır (Fotoğraf 4) [4] . 


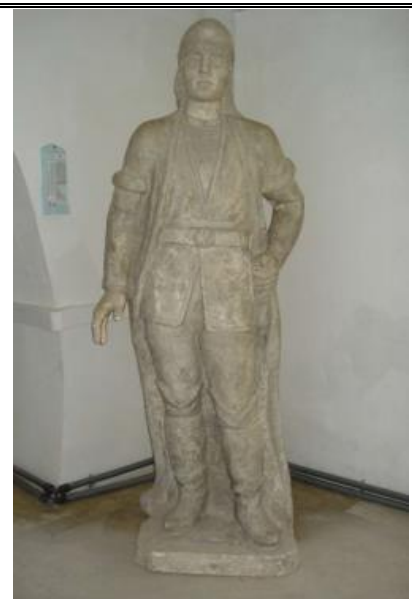

Fotoğraf 4. Dizüstü uzun çizme

(Photograph 4. Laptop long boot)

- Giysilerde ve farklı objelerde aplike kullanılmıştır [3].

- Baharlık giysiler keçe ve yünle kapitone yapılarak kullanılır [3] .

- Blucin kumaşının tüm dünyada kullanılması Denizli ilinden yayılmıştır, kalın mavi bez [27].

- Fötr şapkanın dünya giyim kültürüne etkisi Kırgız şapkalarından esinlenilmiştir [6].

- Farklı bay ve bayan şapkaları kullanılmıştır (Şekil 8) [19] .
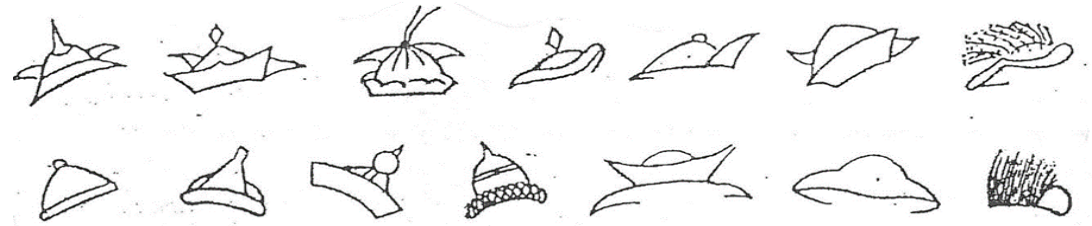

Sekil 8. Selçuklular döneminde giyilen bazı başlıklar (Image 8. Some headgear worn during the seljuk period)

- Cepkenin bolero olarak kullanılması Türklerden alınmıştır [3].

- Salta denilen Jabo kullanımı da Türklerden alınmıştır [3].

- Çizme, çarık kullanımı [3].

- Taç kullanımı [4]

- Duvak kullanımı [3].

- Kırmızı gelinlik kullanımı [3].

- Kırmızı rengin bulunması ve kullanılması üç rengin kırmızı yeşil ve sarının çok önemli renk olarak ölülere bile giydirilmesi geleneği vardır [3].

- Keteni ilk Türkler kullanmıştır [3] .

- Gömleği Romalılar ilk kez Hunlarda görmüştür. Avrupa'ya Hunlarla yayılmıştır [3].

- Güzellik kraliçelerinde kullanılan bandananın bir Türk kültürü geleneği olduğu bilinmektedir (Şekil 9) . 


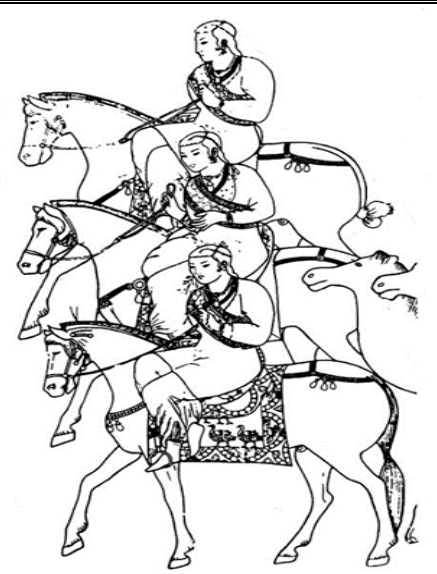

Şekil 9. Köktürk Devlet duvar resimlerinde düğün alayındaki atlı, pantolonlu genç kız bölüğü

(Image 9. The young girl's squad with horse and pants in the wedding procession in the Köktürk state murals)

- At kılından yapılan ilk gözlük Türkler tarafından kullanılmıştır [3] .

- Dövme kullanımı [3].

- Makyaj (Yüz yazma) kullanımı [3].

- Smokin ceket (Önü kısa arkası uzun) kullanımı [4].

- Ceket kullanimi [4].

- Üniforma kullanımı [4].

- Pelerin kullanımı (Yaz ve kış pelerini) [4]

- Kravat kullanım çoban kepeneklerinin birleştirilip kapatılmasıyla başlamıştır [26].

- Boyun bağı kullanımı [26].

- Çanta (Togar) kullanımi [4].

- Altin örerek kumaş haline getirip börk, ceket, pantolon ve çizme aksesuarı yapılmıştır (Altın Elbiseli Adam örneği) (Fotoğraf 56) [3] .

- Keçe çorap kullanımı (Şekil 10).

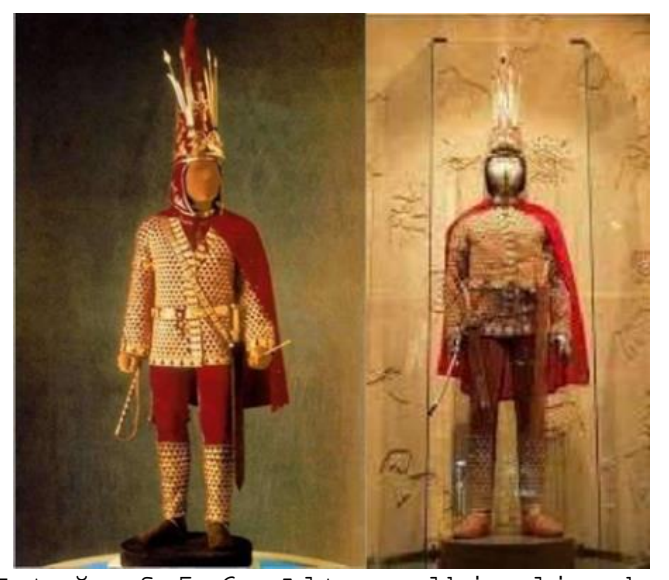

Fotoğraf 5-6. Altın elbiseli adam

(Photograph 5-6. Man in golden süit) 


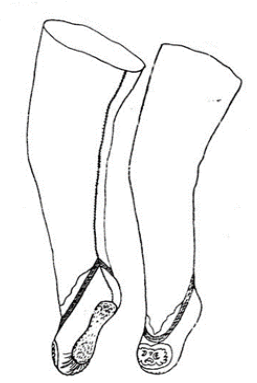

Şekil 10. Motifli ayakkabı numarası

(Image 10. Shoes with motifs)

- Askeri giysilerde ilk defa börk, pantolon, ceket, çizme kullanılmıştır [18].

- Asa kullanılmıştır [10].

- Peruk kullanılmıştır [4].

- Hotozlu şapka kullanılmıştır [3].

- Saç süsleri kullanılmıştır [3].

- Maske kullanımı [3].

- Her toplumda olduğu gibi, Türklerin giyim kültürü de tarih boyunca farklı değişmeler kaydetmiştir.

\section{MATERYAL VE YÖNTEM (MATERIAL AND METHOD)}

Araştırmanın materyalini konu ile ilgili kaynakların taranmasından elde edilen ve resimler teşkil etmektedir. Yöntem Araştırmada tarama ve saha çalışma yöntemi izlenmiştir. Bu amaçla geleneksel Türk giysileriyle ilgili literatür ve görsel kaynak taraması yapılmış, Londra Central Saint Martins College of Art and Design School, Royal College gibi çeşitli moda okulları ile Asya, Avrupa müze ve kütüphanelerin de araştırma yapılarak, kaynak kişilerle görüşülerek, resim ve bilgiler amaç doğrultusunda düzenlenmiş araştırmanın ilgili bölümlerinde sunulmuştur [2] .

\section{BULGULAR (RESULTS)}

\section{1. Şalvar Pantolon (Shalwar Trousers)}

Bilindiği üzere yeryüzünde atı ilk evcilleştiren ve atı binek hayvanı olarak kullanıp eğeri, üzengiyi kullanan ilk kavim Türk'lerdir. Tarih boyunca Türkler ata binen hatta hayatı at üzerinde geçiren insanlardı. Onlar için çalılara, taşlara, soğuğa ve uzun at yolculuklarına dayanıklı giysiler gerekliydi. Bu nedenle, ata binmede karşılaşabilecekleri sürtünme ve bacaklarda yara açılması gibi tehlikelerden korunmak için kalın pantolon ve çizme giymek zorunda kalmışlardır. Uzun at yolculuklarına çıkacak olan kişiler özellikle deri pantolonlar kullanmışlardır [18]. Çok soğuk havalarda kürk pantolonlar giymişlerdir. Bugün hala Türklerin eski anayurdu olan Moğolistan’ın Orhun bölgesinde kışın soğuklarda kürklü pantolonlar giyilmektedir [3]. Yeryüzünde ilk atlı milleti olan Türkler pantolon ve ceketi ilk kullanan kavim de olmuşlardır. Çünkü pantolon ve ceket süvari giysisidir. Bir süvarinin içinde en rahat edeceği giysi pantolon ve cekettir. Pantolon, belden aşağısına giyilen ve bacakları saran diz altından ayak bileğine kadar farklı boyda yapılabilen kadın ve erkeklerin rahatlıkla kullanabildiği bir alt giysi çeşididir [3] .

Başka bir tanımla pantolon, belden ayak bileklerine uzanan ve her bacağı ayrı ayrı saracak biçimde iki parçadan oluşan bir giysidir [1]. Türklerin üzerine kaftan giymelerinden dolayı pantolonlar pek çok kaynakta iç giyim olarak ele alınmıştır [18]. Orta Asya step ulusu olarak Türklerin Batı dünyasına taşıyıp benimsettikleri pantolon adını 
alan altlıklar yalnız Türk giyim tarihi açısından değil, dünya giyim tarihi açısından da olağanüstü öneme sahiptir. Avrupa pantolonlara ilk kez 18. yy'da yani Türklerden bin yıl sonra giyinmeye İtalyan komedyen Pantolone aracılığı ile başlamıştır [8]. Şalvar ve pantolon savaşç kavimlerde kişilerin ata binmek için geliştirdikleri bir giysi çeşidi olarak Hunlar tarafından bulunmuştur [18]. Rahat ata binmek için Bizans, Roma ve Çinliler entari giyerlerken, Türk'ler üm adını verdikleri günümüzde süvarilerin kullandığı, paçaları dar, üstü biraz daha geniş olan pantolonu kullanmışlardır [21]. Çin'de atıı birliklerin kurulmaya başlanması ile pantolon giyme zorunluluğu ortaya çıkmışır [3]. Uygur'lar da binek tipi şalvar giyerlerdi (Şekil 11). At üzerinde uzun bir yolculuğa çıkmak isteyen Kazaklar şalbar dedikleri geniş bir seyahat pantolonu giyerlerdi. Kazakların giydikleri pantolonları kaftanların bütün eteklerini içe alacak kadar geniştir. Bu pantolonlar yumuşak deriden yapılmış ve sarıya boyanmıştır. Zengin kesimde bu deri pantolonlar örgülerle dış yüzeyden süslenmiştir.

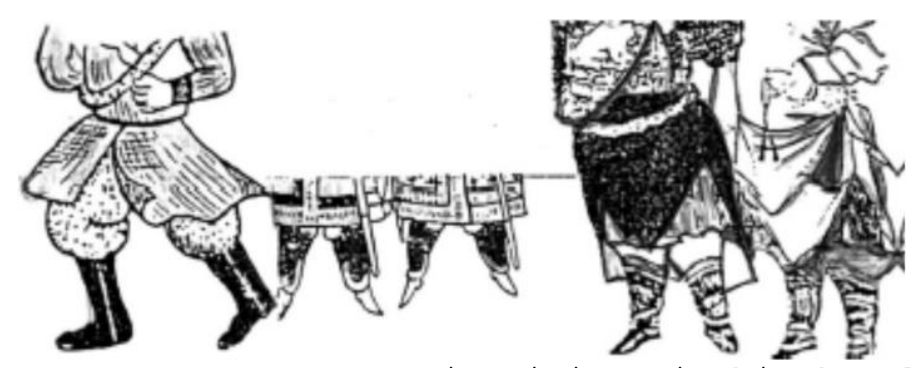

Şekil 11. Uygur ve Orta Asya Çin tipi geniş binek Şalvarı [18] (Image 11. Uyghur and Central Asian Chinese type wide riding shalwar)

Ziraatçı olan Tarancı Türkleri ketenden yapılmış ince ve geniş şalvarlar giyerlerdi. Demir çağına ait Türk mezarlarındaki bulgularda daha çok paçaları dar pantolonlara rastlanmıştır. Bu pantolonlarda ayrıca paça bağları da görülmüştür. Orhun kurganlarından çıkan bu pantolon örnekleri Fotoğraf 7 ve 8'de görülmektedir [3].

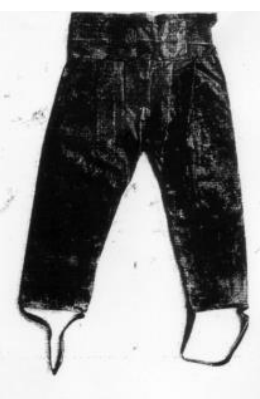

Fotoğraf 7. Kurganlardan çıkan ilk Türk pantolonu (Ön) [3] (Photograph 7. First Turkish pants coming out of Kurgans (Front))

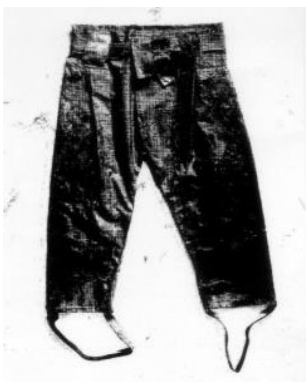

Fotoğraf 8. Kurganlardan çıkan ilk Türk pantolonu (Arka) [3]

(Photograph 8. The first Turkish pants from the Kurgans (Back))

Kurganlardan çıkan ilk Türk pantolonu, Moğolistan (Ön ve Arka). Türkler çeşitli şalvar formlarını geliştirip kullanmışlar ve bu farklı şalvarların don, çakşır, potur, zıpkazivga vb. gibi bölgesel isimlerde kullanmışlardır. Türkmenlerin dizi hemen altında bağlanacak şekilde zeybek donlarını anımsatan kısa şalvar tipi bu alt giysiye sahip oldukları da bilinmektedir (Şekil 12). 

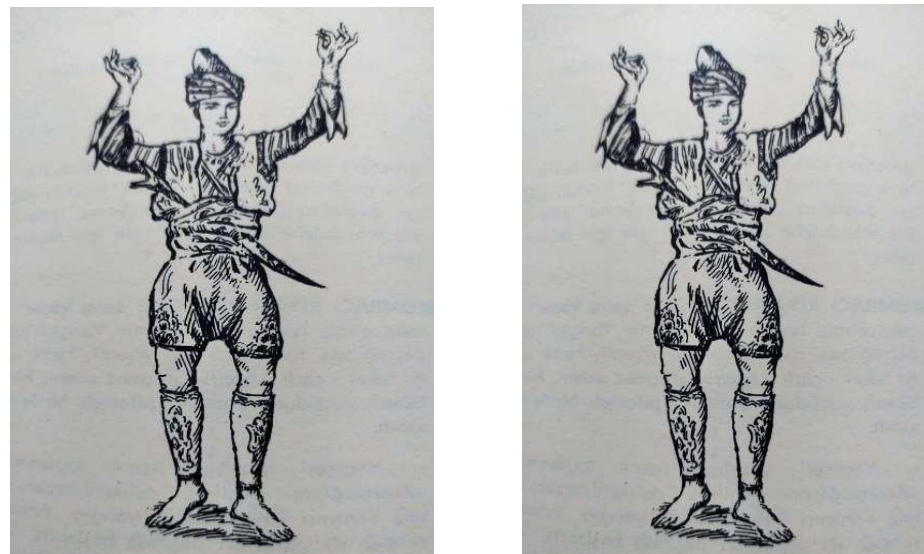

Şekil 12. Zeybek kıyafetine benzer çakşır (Don ve tozluklar) [15]

(Image 12. Flint similar to Zeybek outfit (Frost and leggings))

Zeybek kıyafetinde benzer çakşır(don) ve tozluklar 13. yy 'da Konya'da yazılan Varka ve Gülşah adlı mesnevinin minyatürlerinde görülen kıyafetlerde, üstlüklerin altına şalvarı düz paçalı kadınlar, eski Türk geleneğine uygun başlıklar taşıyan şalvarlı ve çizmeli erkekler ve üstlükleri üzerine takılan kuşaklar ve bağlantılar dikkat çekmektedir [20]. Türklerde kadın ve erkek halk giyimi Avrupa'da olduğu gibi çok farklılık göstermemiştir. O dönemlerde aynı tarz giyindikleri görülmektedir. Türklerde giyilen pantolon çeşitleri farklı isimlerde olup genel olarak aynı biçimdedir. Bunlar potur, çakşır ve dondur. Yöresel farklılıkları bulunmuştur.

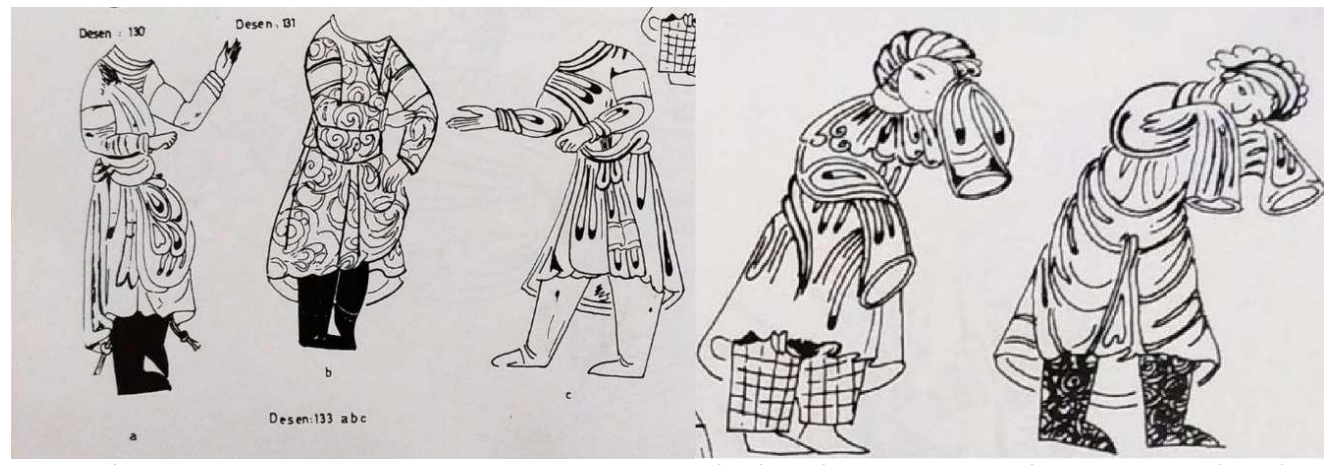

Şekil 13. Varka ve Gülşah mesnevisi minyatürlerinden çeşitli kıyafetler [19]

(Image 13. Various outfits from Varka and Gülşah mesnevi miniatures)

\subsection{Potur (Potur-Pot)}

Erkekler tarafından vücudun belden aşağı kısmında giyilen kalça bölgesi oldukça dökümlü, ayak bileği ile diz arasındaki mesafesi sıkı görünümlü giyimdir. Potur adını kırma ve buruşuk anlamındaki pot isminden almıştır. Poturun özelliği; belden dökümlü inen giyimin dizden aşağı teni sarması ve paça kısımlarının önünde arkasında birer yırtmaç görünümlü poletçik bulunmaktadır. Poturun paçası dikişli bir tozlu görünümündedir ve genellikle cepken altına giyilmiştir. Çoğunlukla Rumeli bölgesinde tercih edilen bir giyimdir [15]. 


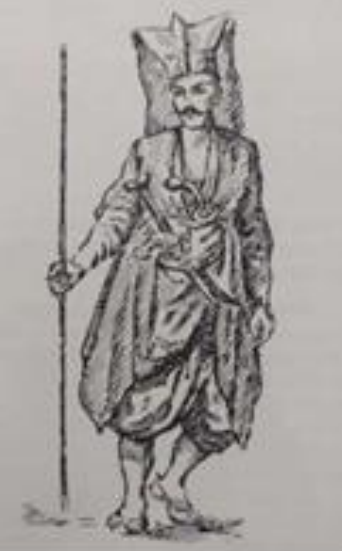

Şekil 14. Şalvar örneği

(Image 14. Shalwar example)

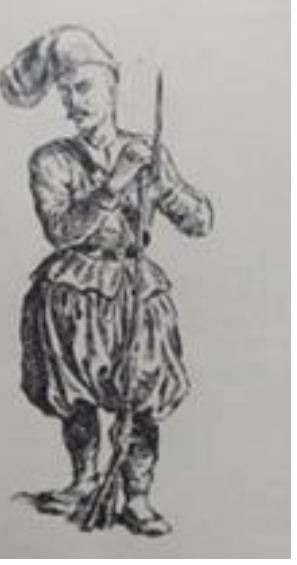

Şekil 15. Şalvar örneği (Image 15. Shalwar example)

\section{3. Çakşır (Çakşır)}

Bazı bölgelerde Karadan ve Zıbka adıyla anılır. Çakşırın iki çeşidi vardır. Her iki çeşidi de yaşları 45'in altında olan genç erkekler ve özellikle koşarlı hizmet erleri, asker ocaklarında neferler, çavuşlar, resmi kuruluşlarda hizmetliler ve hizmet çeşitlerine göre çeşitli isim alan uşaklar giymiştir. Çakşır belden uçkurluğuna geçirilmiş bir uçkur ile bele yerleştirilir. Diz kapağından aşağısı baldırı örten kısmı birden daralır. Bazı durumlarda çakşırın paçasına ince ve yumuşak deriden bir mes dikilerek eklenir. Çakşırla birlikte mest de giyilir. Diz çakşırı ise yeniçeriler tarafından giyilmiştir. Diz kapağının üstünde biten dizden aşağısı çıplak kalan bir giyimdir. Bazı durumlarda diz kapağı altından ayak bileğine kadar tozluk geçirilmiş ve örtülmüştür [15]. Eskiden dışa giyilen giysilerin tümüne don, giyinmek ve kuşanmak eylemine de donanmak denilse de don sonradan kısalan uzun şalvarlar için kullanılan bir sözcük olarak kalmış, hatta daha sonraları iç çamaşırı anlamında sadece içe giyilen şalvarlar için kullanılmaya başlanmıştır. Kısa şalvarlara sonradan çakşır da denmeye başlanmıştır.

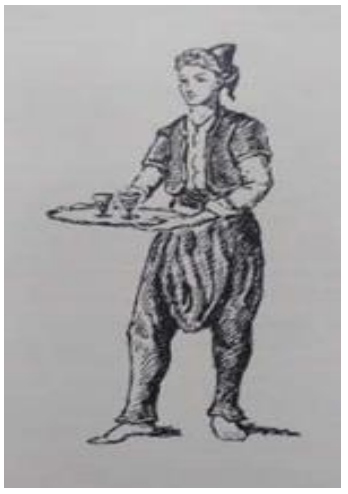

Şekil 16. Şalvar örneği

(Image 16. Shalwar example)

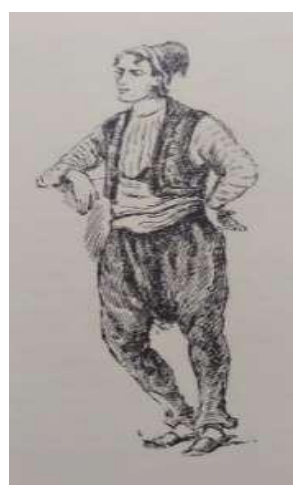

Şekil 17. Şalvar örneği (Image 17. Shalwar example)

\subsection{Don (Underwear)}

İç donu ve tuman ismiyle de anılmıştır. Vücudu belden aşağı topuklara kadar örten ve bacaklar için iki parçası bulunan bir giyimdir. Erkek ve kadın için giyilenlerin kesimi aynı olmuştur. Bürümcük, Trabzon bezi, kaba bez kullanılmıştır. Zamanımızda yaşlı kesimin muhafazakarları, köylerde yaşayanların bir bölümü bu tarz giyimi halen sürdürmektedirler. Paçalara bağcık yerine ilik-düğme 
yapılanları, uçkur yerine de belden düğme ile tutturulanları veya uçkur kısmına lastik geçirilmiş olanları, yarım asırlık birer geçmişi olan türlerdir. Diz çakşırı giymeye mecbur olanların iç donları da yine belli uçkurlu ve ağ kesimi boldur. Fakat boyu diz kapağının üzerindedir. Diz kapağının üstünde kalan kısa erkek donları I. Dünya Savaşından sonra yayılmıştır. Saraylı kesimin iç donları bürümcük kumaştan kesilmiş ve üzerine çintemani denilen bir nakış yapılmıştır (Şekil 18).

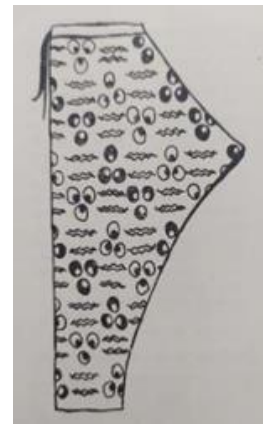

Şekil 18. Şalvar örneği

(Image 18. Shalwar example)

Doğu Türkistan şalvarı olarak bilinen ayak bileğinden torbalı (bağlı) şalvarlar, Anadolu'da daha çok kadınlar tarafından yaygın olarak kullanılmıştır. Paçası lastikli ya da bağcıklı bu tip şalvarların, bugün bir spor giyim ürünü ya da ev giysisi olarak yaygın bir şekilde kullanılmakta olan eşofman altlarının da atası olduğu düşünülmektedir [16]. Marc Jacobson ve Gian Franco Ferre'nin koleksiyonunda şalvar formlarının dışında bel bağlamaları, katlı giyim tarzı ve türbanların da Türk giyim kültüründen etkilendiği açıkça görülmektedir (Eotoğraf 9, 10, 11, 12 ve 13). Günümüz giyiminde tüm dünyada kullanılan şalvar, farklı boy ve kesimlerle modernleştirilerek trendlere uygun yapılmıştır (Şekil 19).
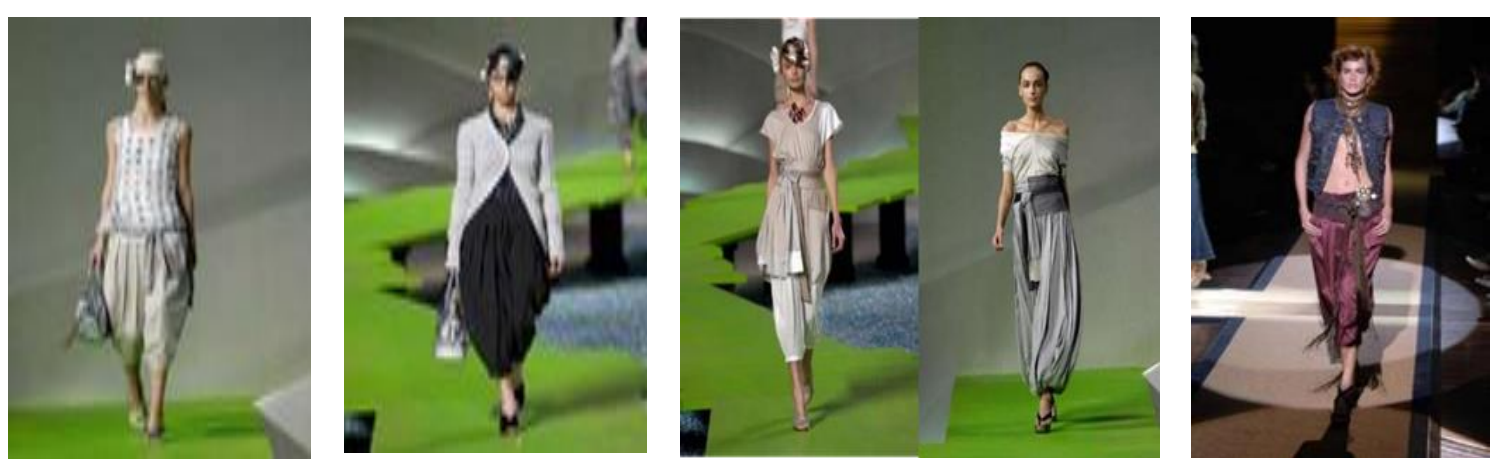

Fotoğraf 9, 10, 11, 12 ve 13. Şalvar örneği [22]

(Photograph 9, 10, 11, 12 and 13. Shalwar example) 


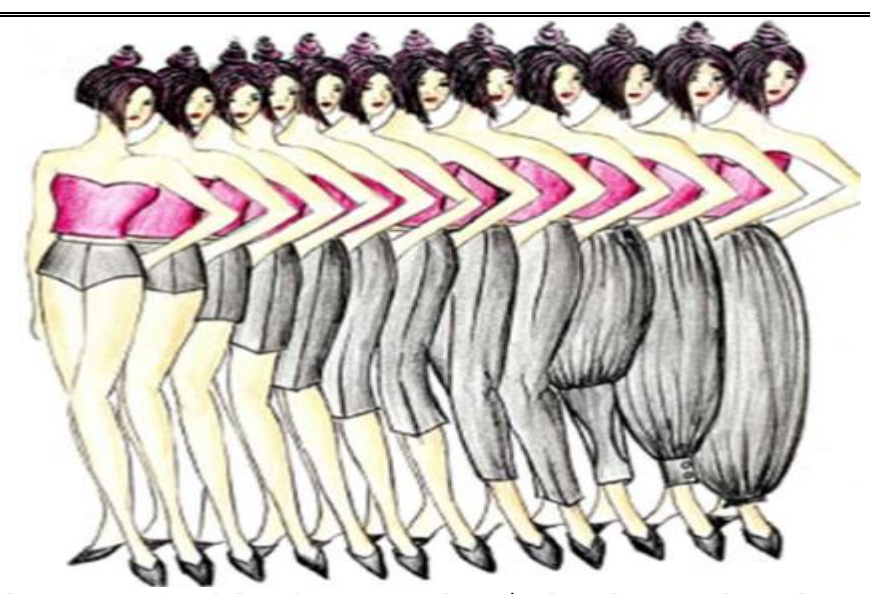

Şekil 19. Şalvarın farklı boy ve kesimlerle modernleştirilmesi [5]

(Image 19. Modernizing the shalwar with different sizes and cuts)

\section{5. Üstlükler (Top Dresses)}

Bozkır uluslarının göçebe kültürüne sahip olmaları, at üzerinde sık sık konar göçer yaşam sürmeleri, onların uzun süreler at sırtında kalmalarına sebep olduğundan, at sırtında entari ya da önü kapalı uzun tunik şeklinde üstlükler giymeleri pek kullanışlı ve rahat değildi. Bu sebepten at sırtında entari veya uzun tunikler yerine bacakları ayrı ayrı saran şalvar şeklinde pantolonlar, önü açık ve etekleri genellikle ata binerken şalvar içine sokulan üstlüğün eteklerinin sokulması uygulaması Osmanlı resmi kıyafetlerinde ve yakın geçmişe kadar Güneydoğu Anadolu'da da görülmekteydi. Yırtmaçlı kaftanların, özellikle de üç etek üstlüklerin, hem estetik kaygllarla alta giyilen giysinin materyal ve süslemelerini gösterecek tarzda, hem de hareket serbestisini sağlayacak şekilde geliştirildiği ve etek uçlarının beldeki kuşak ya da şalvar içine rahat bir şekilde sokulabilmesi için yırtmaçlı yapıldığı düşünülmektedir [16]. Türklerde kadın ve erkek giysilerinde farklılıklar pek yoktur [29]. Sosyal yaşantı itibariyle de erkeklerle aynı konumda bulunuyorlardı. Türkler, Selçuklu döneminde ve bunun öncesi ve sonrasında önden açılıp kapanan çeşitli üst giysiler giymişlerdir. Uzun, orta uzunlukta, kalça hizası ve kalça üzerinde olmak üzere çeşitli boylarda olanları vardır. Her ne kadar Türk'ler ve Perslerin temel üstlük formları birbirine çok benzese de gerçek Pers kaftanlarının diyagonal kesimli kapalı yakalı ve soldan sağa doğru yan dikişlerde kapandıkları, bugünkü adıyla kruvaze formlarda oldukları, diğer taraftan Türk kaftanlarının ise ön ortada kapandıkları söylenir [13 ve 25]. Moğolistan'daki Orhun anıtlarındaki heykellerin üzerindeki giysilerin önden açık bele kadar kemerle ve kuşakla birleştiği görülmektedir [3]. Bazı türleri eskiden beri boyundan bele kadar iliklenmekte, bu işlem süslü kaytan ve britlerle yapılmaktaydı. Bu model Osmanlı Imparatorluğu döneminde de çok yaygın olarak kullanılmıştır [16]. Üstlükler içerisinde en yaygın olanı kaftanlardır. Bu uzun, diz altı ya da ayak bileğine kadar uzanan üstlüklerdir. Kaftanların yakalı, yakasız, kapalı yakalılar, V yakalılar, uzun kollular, kısa kollular, kuşaklı, önden ilikli, kol yenleri bol olanlar, kürklü olanlar, yakası kürklüler, astarlı, astarsız gibi pek çok çeşidi vardır. Bazı çevreler kısa kollu üst kaftanlarını tipik Türk giysisi olarak kabul ederler. Bunların bazılarında bele kadar veya daha aşağıda biten yırtmaçlar varsa da Türk kaftanlarının genellikle arkadan yırtmaçsız olduğu bilinir. İlk örnekleri Selçuklularda görülen üç etek üstlüklerde iki yanda yırtmaç bulunmaktadır ve bir çeşit yırtmaçlı kaftanlar kategorisinde sayılabileceği düşünülmektedir. Yakın zamanlara kadar Anadolu 
kadınları arasında yaygın olarak giyilen bu üç etek entarilerin bazı tasvirlerinde eteklerinin bele toplandıklarına veya kemere sokulduklarına tanık oluyoruz. Yakın zamanlara kadar Anadolu kadınları arasında yaygın olarak giyilen bu üç etek entarilerin selçuklular döneminde erkekler tarafından da giyildiği bilinmektedir. Kaftan ve cepken kollarının bazen giyilmeyip sarkıtıldığı bunun bir gelenek halinde Osmanlı döneminde de sürdürüldüğü bilinmektedir.

Kaftanların çoğu altın sırma yahut ibrişimle işlenmekte veya bitkisel motifli kumaşlardan yapılmaktaydı. Kısa cekete benzer üstlüklere çekrek çekmen gibi isimler verilmiştir. Bel hizasında veya daha kısa uzun kollu, önü kapamasız bir üstlük olan cepkenin bu sözcüklerden türediği sanılmaktadır [20]. Bugünkü adıyla boleronun cepkenden geldiği düşünülmektedir. Kaftandan üretilen bir diğer giysi de gömleklerdir. Bazı kaynaklarda biraz farklı adlandırılsalar da günümüzdekilerle benzeyen sözcüklerle geçmektedirler gömlek, köynek, içlik vs. Dede Korkut Hikayelerinde göynek boğmakladı diye geçen ibarenin gömleğin düğmelendiği anlamına geldiği bilinmektedir. Kolsuz kaftandan türetilen bir dış giyim ürünü de yeleklerdir. Türk'ler arasında bağırdak denilen kadın yelekleri ise Anadolu Türkmen'leri tarafından her dönemde giyilen giysiler arasında yer almıştır. Fotoğraf 14'de Dries Van Noten'ın Türk yelek formlarından ve süsleme sanatından etkilenerek hazırladığı bir güncel yelek tasarımı görülmektedir.

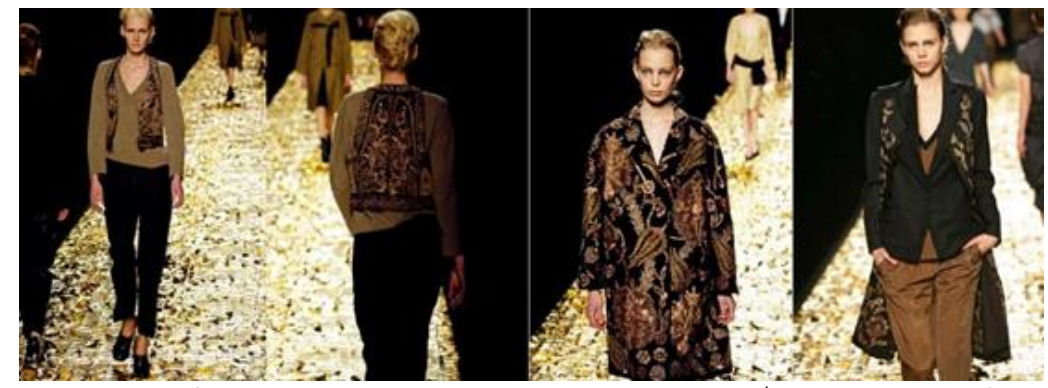

Fotoğraf 14. Dries Van Noten 2006 sonbahar/kış koleksiyonu [23]

(Photograph 14. Dries Van Noten 2006 fall/winter collection)

\subsection{Katlı Giyim Tarzı (Double Layer Clothing Style)}

Türk giyim kültürünün en önemli özelliklerinden biri de giysilerin hem fonksiyonel hem de estetik bir anlayışla üst üste giyilmesiydi. Giysiler gelişigüzel üst üste giyilmez, tüm katlardaki giysilerin materyalleri ve dekoratif süslemeleri bir şekilde üstten görünecek şekilde estetik bir anlayışla tasarlanır ve düzenlenirdi. Türkler, cepkenler, kaftanlar ve yeleklerin altına sıcak tutması için gömlek ya da iç entariler giyerlerdi. Bu katlı, üst üste giyilen giysiler önden açık olduklarından özellikle at üzerindeyken bile hava şartlarına göre kolayca giyinip soyunmaya imkan sağlamaktaydı. Katlı giyimin üç temel fonksiyonu vardı: Sıcak tutma, Kullanım kolaylığı, kolaylıkla soyunma ve giyinebilme, Estetik arayış Fotoğraf 15'de Gian Franco Ferre'nin İlkbahar/Yaz 2006 hazır giyim koleksiyonunda, formsal tasarım elementleri ve tasarım detayları açısından Türk giyim kültürünün karakteristik özelliklerinden etkileri görmekteyiz [9]. Ferre'nin bu koleksiyonunda, alttaki giysinin materyali ve diğer dekoratif özellikleri görünecek şekilde zengin bir düzenleme ve estetik bir anlayışla katıı giyim tarzı ön plana çıkarılmış. 


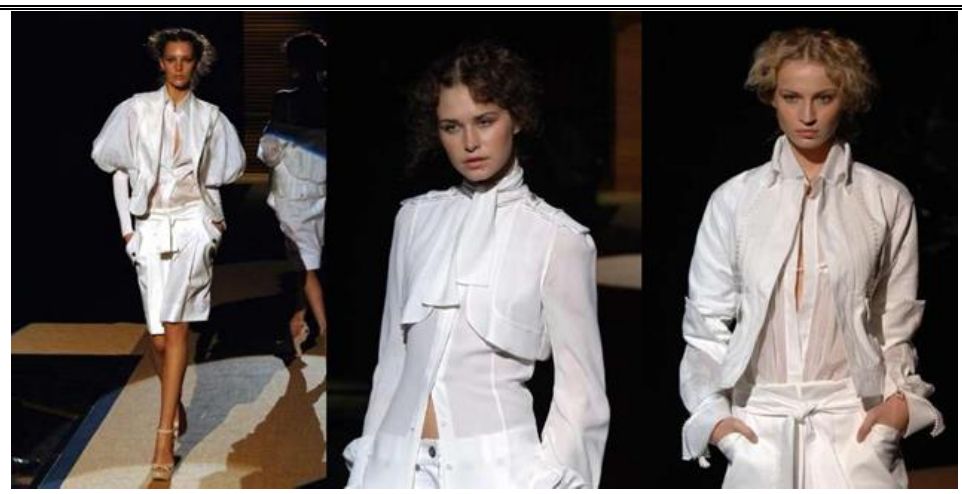

Fotoğraf 15. Katlı giyime örnekler (Gian Franco Ferre ilkbahar/yaz koleksiyonu 2006) [7]

(Photograph 15. Examples of layered clothing (Gian Franco Ferre spring/summer collection 2006)

Altta bol kesimli, uzun kollu, önden açık, yakasız ya da küçük yakalı gömlek, bluz, mintan vb. giysiler, bunların üzerinde daha dar kisa kollu ya da kolsuz cepkenler, ceketler, yelekler ya da bluzlar tasarlanmış. Bu koleksiyondaki üst üste giyim sıralamasındaki estetik anlayış, kol ağzı ve yaka formları, ön kapamalar, kemer ve kuşaklı bağlamalar Türk giyim tarzından etkilenmelere tipik bir örnek teşkil etmektedir [16].

\subsection{Kuşaklar (Belts)}

İlk etapta önden açık giysi kullanımının zaruri bir neticesi olarak ortaya çıktığı düşünülen kuşaklar, özellikle düğmenin icat olmadığı dönemler de hem üstlüklerin önünü kapatmak hem de kişisel eşyaları taşımak amacıyla kullanılmışlardır. Bu fonksiyonel amacın dışında daha sonraları estetik kaygılarla da çeşitli kuşak kullanımları ve bağlama şekilleri geliştirilmiştir. Orta Asya Türklerinde, kaftan üzerine, çok yaygın bir gelenek halinde, iki türlü kuşak bağlandığı bilinmektedir. Bel bağı da denilen bu kuşaklar, kumaştan ve deriden yapılıyordu. Yün kuşak sardıktan sonra bazen ayrıca deriden bir kuşakla bağlanırdı. Bazen yün kuşaklar köprücük kemiğine kadar geniş bir şekilde bağlanmaktaydı. Ayrıca eski Türk komutanlarının ve hükümdarların genellikle deriden ince kemer taktıkları, bunların bazen ikili olduğu, bazen rütbe belirttiği, ayrıca çeşitli araç-gereç, silah gibi kişisel eşyaları taşımaya yönelik sarkancaların sarkıtıldığı da bilinmektedir. Diğer taraftan gerek altlıklar gerekse üstlükler üzerine çeşitli kumaşlarda ve kalınlıklarda kuşakların sarılması ve uçlarının sarkıtılması da Türk giyim kültürünün en karakteristik özelliklerinden birisi olarak karşımıza çıkmaktadır. Cins ayrımı olmadan, kadın ve erkeklerde hata aristokrat kesimde yaygın olduğu gözlenen kumaş sarkıtma geleneği, bazen uçları işlemeli şalvar uçkurları olarak da aynı anlayışla Anadolu kadınlarında uzun süre yaşamıştır [20]. İkili kemer örnekleri ve sarkıntılı kemer örnekleri Türk giyiminin vazgeçilmez aksesuarlarındandır. Günümüz giyim modasında kuşak kullanımı ve ikili kemer uygulamaları da oldukça dikkat çekmektedir. Örneğin Fotoğraf 16, 17 ve 18'de Dries Van Noten'ın ve Marc Jacobs'un tasarımlarında Türk tarzı kuşakla bağlamalara tipik örnekler görülmekte [16 ve 24]. 


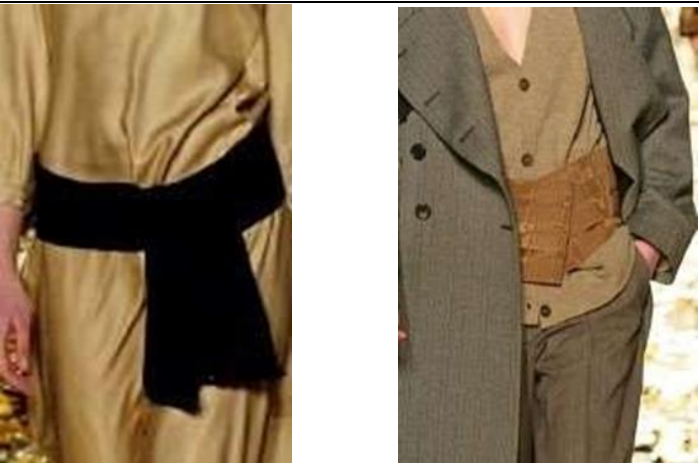

Fotoğraf 16 ve 17. Dries Van Noten sonbahar/kıs 2006

(Photograph 16 and 17. Dries Van Noten fall/winter 2006)

Şalvar tasarımları Ingiltere'de güncelliğini korumaktadır [5] .

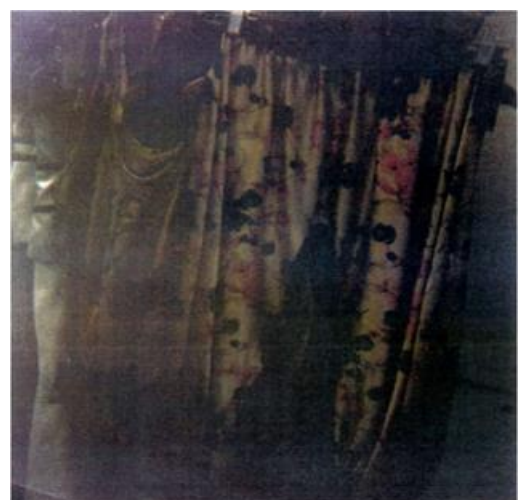

Fotoğraf 19. Central Saint Martins college of art and design school [5]

(Photograph 19. Central Saint Martins college of art and design school)

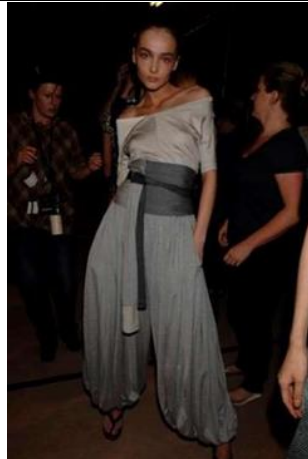

Fotoğraf 18. Marc Jacobs

ilkbahar/yaz 2007

(Photograph 18. Marc Jacobs spring/summer 2007)

moda okullarında tema olarak

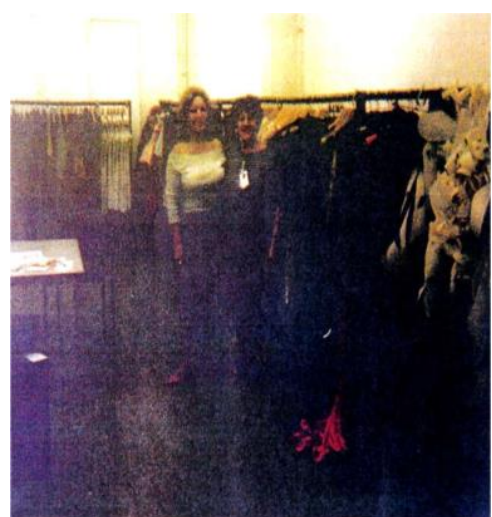

Fotoğraf 20. Central saint Martins college of art and design school [5]

(Photograph 20. Central Saint Martins college of art and design school)

\section{Türklerde şapka kullanımı vardı ancak Müslüman olduktan sonra sarık ve fes kullanılmıştır [3]. Osmanlı giyim tarzının en karakteristik özelliklerinden birisi de basllklar, özellikle de} türbanlar olmuştur. Bunlar, kaftan ve şalvarlardan sonra, Batının Doğudan etkilendiği en önemli giysi formlarından birisi olmuştur. Batıda kraliyet taçlarının dışında başlıklar sadece fonksiyonel amaçla giyilirken, Türklerde başlıklar baştan beri bir cinsiyet, statü ve aidiyet göstergesi olarak kullanılmıştır [16]. Fotoğraf 21, 22 ve 23'de, Prada'nın ve Marc Jacobs'un türbandan ve Jean Paul Gaultier'in festen etkilenerek hazırladıkları başlık tasarımları görülmektedir. 


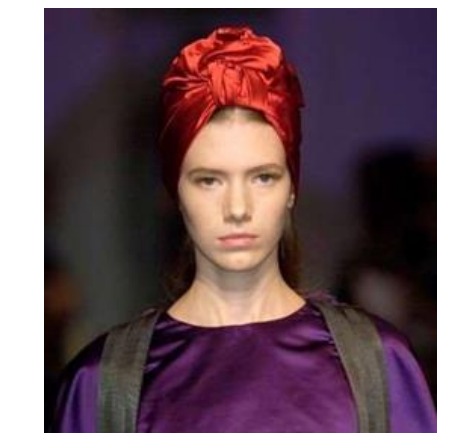

Prada Spring/Summer 2007

Fotoğraf 20, 21 ve 23. Giyim modasında türban ve festen etkilenmeler (Photograph 20, 21 and 23. Influences from turban and fez in clothing fashion)

\subsection{Kumaş Desen ve Motif Tasarımlarından Etkilenmeler (Influences from Fabric, Pattern and Motif Designs)}

Türk motif, desen ve renklerden Batının etkilenmesi oldukça eskidir, Hazar prensesi Çiçek'in Bizans sarayına gelin gittiği zaman giydiği Türk tipi imparatoriçelik elbisesi çiçekion (çiçek adıyla) moda olmuştur. Bizans'ta ilk renkli ipek ve kumaşlar Konçu (Prenses) Çiçek ile gelmiştir. İtalyan Versace'nin Türk desen ve motiflerini eşarp ve ipeklerinde çok kullandığı da bilinmektedir [5]. Türk motif ve desenleri tüm Batıyı oldukça etkilemiştir. Osmanlı giysilerinin Paris modasında oldukça etkili olduğu da görülmektedir. Türk motif ve desenlerinin, Batı giyim modasının yanı sıra birçok objede kullanıldığı da bilinmektedir. Sultan 3. Murat'a ait kaftanın motifleri Dries Van Noten'ın 2006 koleksiyonunda görülmektedir (Fotoğraf 24 ve $25)$.

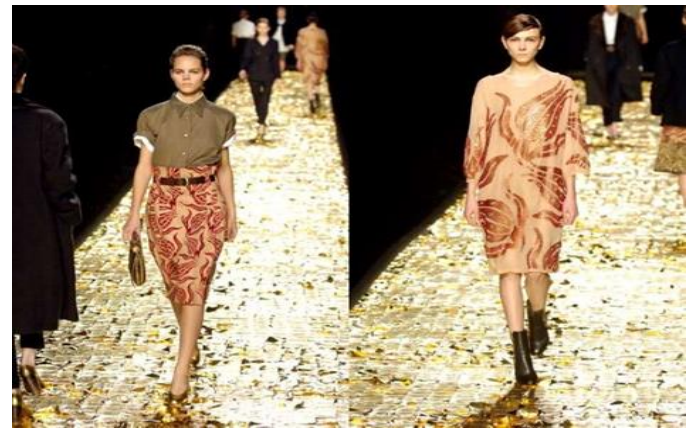

Fotoğraf 24. Osmanlı kumaş desenlerinden etkilenmeler (Dries Van Noten sonbahar/kış Koleksiyonu 2006)

(Photograph 24. Influenced by Ottoman fabric patterns (Dries Van Noten autumn/winter collection 2006))

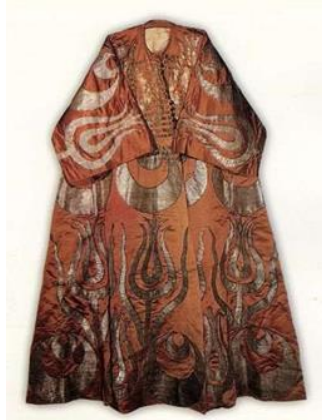

Fotoğraf 25. Sultan III. Murat'a ait bir Osmanlı Kaftanı (16.yy) (Photograph 25. Sultan III. Murat to belong to an Ottoman Caftan) 
6. SONUÇ (RESULT)

Batı modasına ilk etkinin Hunlarla Avrupa'ya gittiğini ve Romalılar da keten gömlek giyildiğini ilk defa Hunlarda görmüşlerdir, renkli giysileri de Batı'ya Türkler getirmiştir. Bozkırın tipik elbisesi ceket-pantolondu. Süvari en rahat şekilde ancak böyle giyinebilirdi. Bugünkü modern giyinmenin ilk tipik örneği olan Bozkır tarzı giyim, Çin'de M.Ö. 4. asırdan, Avrupa'da M.S. 5. asırdan, Bizans'ta 6. asırdan itibaren (daha önceki devirlere ait heykel, kabartma ve resimlerde görülen, bol, uzun ve entari şeklindeki giyinmenin yerini almak üzere) Türk usulüne göre yapılan askeri ıslahat neticesinde, dünyaya yayılmıştır. Başka kavimler kopça kullandıkları halde, Türk'ler düğme kullanırlar ve ceketlerini Çinliler ve Moğolların aksine sola açarlardı. Askeri giysilerde çizme, börk başlık ve arma kullanımı yine ilk defa Türklerden Batı'ya geçmiştir [4]. İlk defa paltu kelimesini Asya'dan gelen bir Turan rrki Sümer'ler kullanmışlardır, palto olarak bugün bile kullanılmaktadır [30]. Pelerini ilk Türklerin kullandığı da bilinmektedir. İlk defa kırmızı rengi ve kırmızı gelinliği, taç ve duvağı ve beden bandanasını Türkler kullanmışlardır (Fotoğraf 26; Şekil 20) [10].

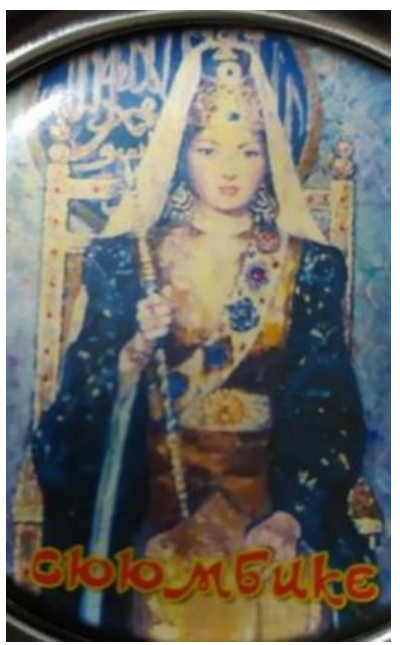

Fotoğraf 26. Suyumbike [4] (Photograph 26. Suyumbike)

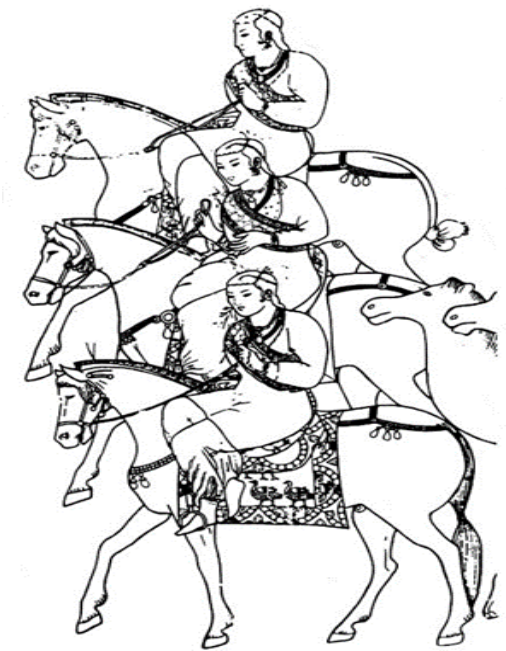

Şekil 20. Köktürk Devlet duvar resimlerinde düğün alayındaki atlı, pantolonlu genç kız bölüğü

(Image 20. Young girl in trousers on horseback in the wedding procession in köktürk state wall paintings) 
Asanın güç belirtisi olarak kullanılması, erkeklerde uzun saç ve küpenin, peruk, dövme ve yüz yazmanın (makyaj), ütünün, togarın (çanta), hotozlu şapkaların kullanılması, ayakkabı numaralama sistemi de Türklerin önemli buluşlarındandır [4]. Burberry deseninin ve swastikanın da (gamalı haç) bir Türk deseni olduğu bilinmelidir (Şekil 21; Fotoğraf 27) [4].

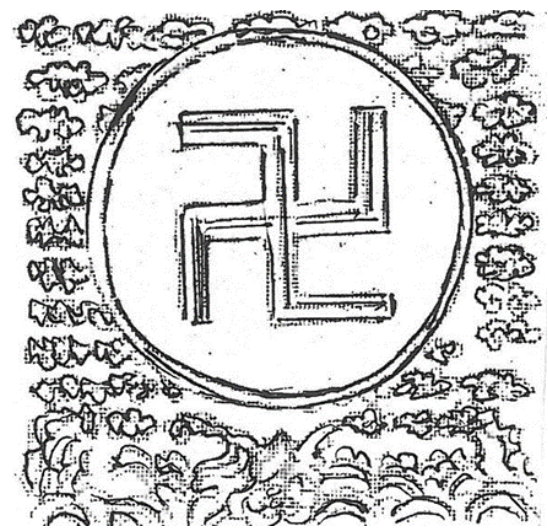

Sekil 21. Swastika-Gamalı Haç Türk'lerde III. derecedeki asker arması (Anlamı: Sonsuzluk)

(Image 21. Swastika-Swastika in Turks III. degree soldier crest (Meaning: Infinity))

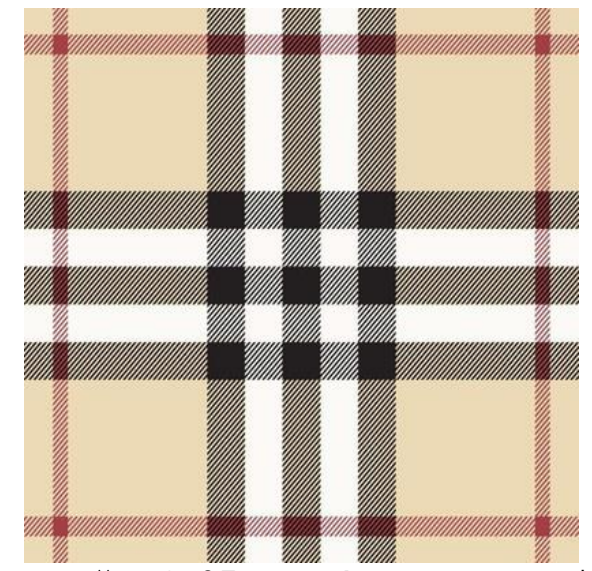

Fotoğraf 27. Burberry Deseni

(Photograph 27. Burberry Pattern)

20.yy. Batılı giyim tarzında çok radikal değişimlere sahne olmuş, özellikle bayan giyiminin temel elementi olan korsenin ortadan kalkmasıyla birlikte rahat ve konforlu giysi formlarına geçilmiştir. Bu yüzyıla kadar Türk erkek ve kadınının temel giysisi son derece rahat olan kaftanlar ve şalvarlar olmuş, ancak 20. yy'da endüstri ve sosyal reformlarla Batıya ayak uydurmaya çalışan yeni Türkiye Cumhuriyeti'nin giyim tarzı da Batının etkisi altında kalmış, bir zamanlar Batının ödünç aldığı temel giysi formlarını yine Batı'nın geliştirdiği yeni formlarıyla pantolon, ceket, manto vb. olarak geri almaya başlamıştır. Kadın erkek benzer giysileri giyen Türk toplumu, özellikle başta kaftan olmak üzere, cepken, ceket, yelek, gömlek gibi kaftandan üretilen üst giysilerle ve şalvar ve şalvardan türetilen pantolon, şort vb. giysilerle Batı'nın giyim kültürünü kökünden etkilemiştir. 20. Yy. bir globalizasyon yüzyılı olarak pek çok şeyden öte, temel Türk giysi formlarının Batı modasını şekillendirdiği ve günümüz global modasına dönüştürdüğü bir yüzyıl olarak hatırlanacaktır [13]. 


\section{7. ÖNERILER (SUGGESTIONS)}

Dünya giyim kuşamına öncülük eden Türk giyim kuşamı, motif ve desenlerini sahiplenerek farklı objelerdeki tasarımların patentleştirilerek Dünya kullanımına sunulmalıdır. Bu zenginliğe rağmen, bir giyim kuşam, desen motif, halı kilim dokuma müzelerimizin olmaması çok üzücüdür, el birliği ile yörenin etnik kültürel özelliklerinin içinde yer aldığı müzeler acilen kurulmalıdır. Dünya başkentleri Washington DC, Londra, Paris, Viyana, Berlin, Moskova, Saint Petersburg, Bakü, Ulan Batur kostüm müzeleri araştırılarak örnek alınmalıdır. Bu başkentlerde tekstil müzesi sayısı oldukça fazladır.

\section{KAYNAKLAR (REFERENCES)}

[1] Ana Britannica. Cilt:3-17-20, ss387. Erişim Tarihi:2019.

[2] Ayhan, F., (2005). Moda Tasarımı Ders Notları.

[3] Ayhan, F., (2000). Moğolistan Orhun Anıtları Araştırmaları.

[4] Ayhan, F., (2002). Moğolistan, Ulan Batur, Tarih Müzesi Araştırmaları.

[5] Ayhan, F., (2004). Londra Araştırma Notları, Central Saint Martins College of Art and Design School, Londra.

[6] Ayhan, F., (2009). Kırgızistan, Bişkek, Tarih Müzesi Araştırma Notları.

[7] Ayhan, F., (2006). Avrupa'da Türk Modası. 3. Uluslararası Balkanlarda İslam Kongresi, 1-5 Kasım, Bükreş, Romanya.

[8] Ayhan, F., (2013). Türk Giyim Kültüründe Pantolon. Akademik Bakış Dergisi 39:(4), Kasım, Aralık, Uluslararası Hakemli Sosyal Bilimler Dergisi İktisat ve Girişimcilik Üniversitesi, Türk Dünyası Kırgız-Türk Sosyal Bilimler Enstitüsü, CelalabatKırgızistan.

[9] Ayhan, F., (2013). Türk Kültüründe Pantolonun Gelişimi ve Dünya Giyim Kültürüne Etkisi. Akademik Bakış Dergisi, Sayı:37, Temmuz-Ağustos 2013 Uluslararası Hakemli Sosyal Bilimler Dergisi, İktisat ve Girişimcilik Üniversitesi, Türk Dünyası Kırgız-Türk Sosyal Bilimler Enstitüsü, Celalabat- Kırgızistan.

[10] Ayhan, F., (2014). Rusya, Kazan Araştırma Notları

[11] Bayar, D., (2000). Orhun Anıtları Heykel Çizimleri, Moğolistan Bilimler Akademisi, Tarih Enstitüsü, Ulan Batur, Moğolistan.

[12] Gülensoy, T., (2001). Pantolon Türk Kültürü. Hürriyet Gazetesi Röportajı, Haber Giriş:24.08.2001. https://www. hurriyet.com.tr/gundem/pantolon-turk-kulturu38261087 .

[13] Jirousek, C., (2004). Ottoman Influences in Western Dress. Ottoman Costumes; Form Textileto Identity.

[14] Faraghi, S. ve Neumann, C., (Eds). İstanbul: Eren Publishing.

[15] Koçu, R.E., (1996). Giyim Kuşam Sözlüğü. Güncel Yayıncılık, İstanbul.

[16] Mete, F., (2006a). Günümüz Giyim Modasında Türk Kültür ve Sanatından Etkilenmelere. Uluslararası Geleneksel Sanatlar Sempozyumu, 16-18 Kasım 2006. Dokuz Eylül Üniversitesi, Güzel Sanatlar Fakültesi, Geleneksel Türk El Sanatları Bölümü (ss: 178-184).

[17] Mete, F., (2006b). The Creative Role of Sources of Inspiration in Clothing Design. International Journal of Clothing Science and Technology, $18(4): 283$.

[18] Ögel, B., (1978). Türk Kültür Tarihine Giriş, Kültür Bakanlığı Yayınları, Ankara.

[19] Süslü, Ö., (1997). Tasvirlere Göre Selçuklu Kıyafetleri, Atatürk Kültür Merkezi, Ankara. 197.

[20] Türkoğlu, S., (2002). Tarih boyunca Anadolu'da Giyim Kuşam 7. İstanbul: Garanti Bankası A.Ş. Yayınları, s.15. 
[21] Zık, H., (2002). Giysi Tasarım Pantolon 1, YA-PA Yayınları, İstanbul. 14 .

[22] http://www.firstview.com. Erişim Tarihi:03.05.2018.

[23] http://www.style.com. Erişim Tarihi: 11.08.2019.

[24] http://www.wgsn.edu.com. Erişim Tarihi: 17.06.2018.

[25] http://www.pbase.com.dosseman. Erişim Tarihi: 13.01.2019.

[26] Prof. Dr. Haşim Turdi, Pekin Üniversitesi, Çin, 2002.

[27] Prof. Dr. Halil, İnalcık Tarihi Profesörü, 2008.

[28] Kazım Mirşan, Göktürk Uzmanı, Görüşme Tarihi:2012.

[29] Örcün Barışta, Sanat Tarihi Profesörü, Görüşme Tarihi:2010.

[30] M. İlmiye Çığ, Sümerolog, Bilim İnsanı, Tarihçi, Görüşme Tarihi:1990. 